\title{
Learning Speaking Through Communicative Grammar On Systematic Functional Linguistics (Sfl)
}

\author{
Edy Suseno \\ edysuseno4@gmail.com
}

IKIP Widya Darma

\begin{abstract}
Practicing speaking is very important for students to exchange ideas with others. Although having learned English for the years, many EFL students face problems in delivering the ideas orally. To overcome this kind of problem, an expo de facto research was conducted by observing the students' scores in two subjects grammar and speaking. The students were in the first semester of the English education major. The research is to find out the material used in teaching grammar to develop speaking learning. To satisfy the aim of this study, the mixedmethod was implemented. The data was analyzed qualitatively and confirmed quantitatively by the applying t-test. From the analysis could be drawn that Using translation-method, podcast, noticing, and conversation in applying the communicative-grammar method enhances the students' competence in speaking. It is very helpful for the teachers and students to implement it in learning grammar and speaking. It also provides the idea to other researchers to dig some deeper innovation in the same field.
\end{abstract}

Keywords: communicative-grammar; podcast; SFL; speaking; translation-method

\section{INTRODUCTION}

People need a tool to interact with others. It is the language. They express their ideas by using their language to exchange information in the form of utterances. They convey a mutual understanding to build a smooth conversation (Koşar \& Bedir, 2014). The use of a language for communication is discourse (Gee, 2014). To practice the communication, people develop speech functions stating, asking, commanding, and answering. It enables the speakers and interlocutors to interact with each other (Halliday \& Matthiessen, 2014).

However, Halliday \& Matthiessen (2014) said that understanding a language is the way to use the language and structure it in spoken and written. To use the language, people need to have sufficient vocabulary and proper pronunciation in their memory. The vocabulary can be meaningful to convey ideas if grammar plays an important role in it. The grammar rule helps people to build sentences to be meaningful in the context. People use the language in formal and informal differently. It depends on the level of formality in both spoken and written. It makes sense the people's world experiences (Martin et al., 2010).Systematic functional linguistics (SFL) is a way to analyze the relationship between social context and linguistic aspects like phonemes, morphemes, lexemes, syntax, and context (Halliday \& Matthiessen, 2014). The use of grammar to build sentences through vocabulary or 
lexicogrammatical functions will put the people into the choice based on the context or situation. It is the way to make the language as functional and meaning-making. It is the core concept of SFL (Halliday, 1978).

The relationship between the context of a situation and linguistic choices is called a register. There are three parts in the register field, tenor, and mode. In the field, people use when and how the lexicogrammatical features like mental verbs and element of cohesion. It leads them to understand what is occurring in the text of the speech and writing. The tenor is about the relationship between writer and readers or among the speakers. It focuses on how and when people choose particular modalities and appraisal. Furthermore, Mode is an analysis of rhetorical features in spoken or written or both. It leads the people to understand how the text is organized (Halliday \& Matthiessen, 2014).

To make the language meaningful to use and to structure in SFL, the three levels of models discourse-semantics, lexico-grammar, and graphology support it. Discourse-Semantic has three metafunctions interpersonal, ideational, and textual. In the lexico-grammar, people use vocabulary to build sentences by implementing grammar rules. To enable the words to be meaningful to express the ideas, people pronounce the words precisely. It is graphology. Regarding Discourse-Semantics and lexico-grammar, SFL models develop them into Experimental meanings (clause as representation), Interpersonal meanings (clause as an exchange), and textual meanings (clause as message) (Eggins, 2004). To establish Interpersonal meaning, the addressee's behavior and influence the color of utterances (Koussouhon \& Dossoumou, 2015). The addresser's attitude and strategy of speaking interferes the success in conversation (Butt et al., 2000)

To enhance lexico-grammar teaching, the teacher can implement the translation method. It is the old method ever used by people to learn grammar to gain meaningful learning. It is in line with SFL's objective to learn the language in a meaningful way. The translation is the process of moving from one language to another. It is the step SFL got started to function (Halliday, 2009). It is the way how translation could be seen as a relationship between units in structures arranged in a hierarchy of ranks and levels (Steiner, 2005). SFL is implemented into some fields like education, translation, computational linguistics, multimodal studies, and healthcare (Matthiessen, 2010).

The relationship between teaching grammar using the translation method and communicative method enables the lexico-grammar learning to become effective in oral communication. It leads the students to learn a language as the use and structure to be meaningful. This communicative grammar, the mixed-method of grammar-translation method, and the communicative method helps both teachers and students discuss the grammar material to enhance the language used to speak (Ho \& Binh, 2014).

Moreover, to teach the students, the teachers need to develop scaffolding. It is a way to help teachers support the teaching-learning process. There are three kinds of scaffoldings content, strategic, and procedure. The content scaffolding discusses the guidance provided by the teacher to help the students learn and do the given tasks. It is the way to answer what and how questions. In strategic scaffolding, the teacher helps the students by providing the process and approach to doing the task. Moreover, in procedural scaffolding, the teachers need to provide the resources, material, and tools to enhance doing the task (Luke et al., 2005). 
The procedural scaffolding helps the students become autonomous. They are very familiar with the use of gadgets. The teacher can foster them to dig some resources on their gadgets to enhance their completion of doing their tasks. One of the resources that provide the various materials for establishing communicative grammar learning is a podcast. It is the resource where the authentic material can be gained. The students can find some audio recordings with the scripts. They can copy the native speakers' way to implement grammar rules in speaking context (Bongey et al., 2006).

In the previous study, Kaharuddin (2018) said that the combination of the grammartranslation method and communicative method enables grammar learning to become effective in speaking setting. Such a mixed-method is called the communicative grammar method. There are three steps in applying this method structural procedure, transitional procedure, and communicative procedure. By applying those steps, the students can implement their grammar usage knowledge into conversation.

Moreover, Baydikova \& Davidenko (2019) said that teaching language focuses on the use of it in communication. It would be meaningful rather than learning the form of it. Learning grammar needs to be linked to the conversation feature to gain meaningful learning. Choosing the grammar topic for communication is beneficial, though. The teacher can choose the more frequent and important grammar rules used in conversation. It helps the students to fluent their competence in speaking.

The two previous studies above do not mention the resources that enhance the students' speaking fluency. To make meaningful sentence buildings, the students need to know how the native speakers use it in real life. By copying the authentic material, the students are able to fluent their ability in speaking. The improper use of grammar in communication leads to misunderstanding among language users.

Many people do not like to learn grammar. It seems that grammar is an activity to memorize some formulas to build sentences. That kind of perspective hampers them to practice speaking (Harmer, 2002). The lack of vocabulary is adding their weakness in expressing their ideas in English. They need a certain way to learn English for communication. Actually, they have already learned English for many years in their life. But, they still find a problem speaking up.

The aim of this study is to prove whether the implementation of the communicative grammar method enhances the students' competence in speaking. To lead the research gaining the intended result, a research question is established. It is "is communicative grammar method effective to develop the students' competence in speaking?" to meet the answer of such a question, the data found was analysis by using mixed-method.

\section{METHOD}

It is expo de facto research. The data of this study is the students' scores in grammar and speaking. The students were freshmen. The scores were owned by fifteen students. They were nine females and six males. The data was analyzed to see the correlation between the two subjects. There were four steps to complete this study. The first step was providing the score list of grammar and speaking. The second was analyzing the data qualitatively. The third is 
inserting the data into the T-test to see the correlation between the two data. The fourth was finding out the material used by the lectures for teaching grammar and speaking. The last one was drawing a conclusion.

\section{FINDINGS AND DISCUSSION}

To gain data for the research, the available score list of grammar lesson was used. It is the first data to analyze. The data deprives some components of assessment participation, task, midterm, final test, and average. This kind of score was the result of the assessment in learning grammar for the freshmen in the first semester. The participants in the class were fifteen. The score range is between 70 and 100. The score list could be seen in table 1 .

Table 1. Grammar scores

\begin{tabular}{llllll}
\hline Number & Participation & Task & Midterm & Final & Average \\
\hline 1 & 100 & 98 & 90 & 92 & 95 \\
\hline 2 & 100 & 70 & 75 & 79 & 81 \\
\hline 3 & 90 & 80 & 80 & 82 & 83 \\
\hline 4 & 95 & 98 & 95 & 97 & 96,25 \\
\hline 6 & 100 & 99 & 90 & 91 & 95 \\
\hline 7 & 100 & 70 & 75 & 79 & 81 \\
\hline 8 & 90 & 94 & 90 & 93 & 91,75 \\
\hline 9 & 95 & 80 & 82 & 84 & 85,25 \\
\hline 10 & 90 & 80 & 81 & 80 & 82,75 \\
\hline 11 & 90 & 90 & 93 & 94 & 91,75 \\
\hline 12 & 100 & 88 & 83 & 84 & 88,75 \\
\hline 13 & 90 & 83 & 80 & 81 & 86 \\
\hline 14 & 100 & 93 & 90 & 91 & 91 \\
\hline 15 & 90 & 94 & 93 & 96 & 93,25 \\
\hline Average & 95,33333 & 87,6 & 86,06667 & 87,86667 & 89,21667 \\
\hline
\end{tabular}

The second data is the score list of the speaking lesson. The students who joined this class are the same as the ones in grammar class. The data comprises some components participation, task, midterm, final test, and average. The range of the scores is between 70 and 100. The scores in the speaking class were analyzed to see the relationship with the scores in a grammar lesson. To see the assessment scores of speaking lessons, table 2 has more.

Table 2. the list of speaking scores

\begin{tabular}{llllll}
\hline Number & Participation & Task & Midterm & Final & Average \\
\hline 1 & 100 & 97 & 94 & 96 & 96,75 \\
\hline 2 & 100 & 70 & 70 & 73 & 78,25 \\
\hline
\end{tabular}




\begin{tabular}{llllll}
\hline 3 & 90 & 80 & 81 & 83 & 83,5 \\
\hline 4 & 95 & 98 & 96 & 97 & 96,5 \\
\hline 5 & 100 & 96 & 93 & 95 & 96 \\
\hline 6 & 100 & 87 & 85 & 87 & 89,75 \\
\hline 8 & 95 & 90 & 93 & 90 & 92 \\
\hline 9 & 90 & 85 & 90 & 87 & 88 \\
\hline 10 & 100 & 97 & 96 & 95 & 97 \\
\hline 11 & 100 & 97 & 96 & 95 & 97 \\
\hline 12 & 90 & 83 & 80 & 82 & 83,75 \\
\hline 13 & 95 & 83 & 84 & 80 & 85,5 \\
\hline 15 & 90 & 89 & 82 & 87 & 88,25 \\
\hline Average & 96 & 90 & 88 & 92 & 90 \\
\hline
\end{tabular}

\section{Result and dicussion}

Graph 1. Participation

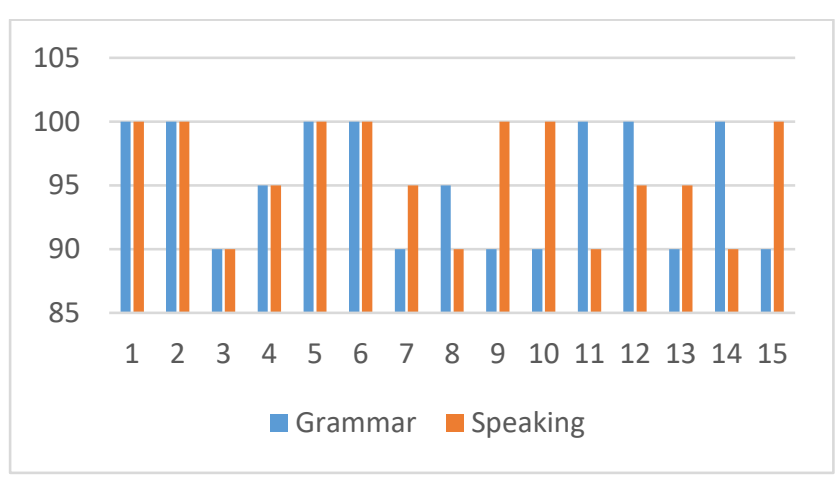

From graph 1, it can be seen that the participation of the participants is between $90 \%$ to $100 \%$. It seems that they were enthusiastic about joining the class. This percentage describes the presence of the students in the two subjects grammar and speaking. There are 4 students who are totally focused on presenting the lectures of the two subjects. They are students number $1,2,5$, and 6 . There are six other students who were attending the class at $100 \%$. They did not attend the lecture on the two subjects at the same frequency. The students' number 9, 10, and 15 totally got involved in following the lesson speaking. They joined the lesson grammar at $90 \%$. The three other students number 11,12 , and 14 joined the lesson grammar $100 \%$. They paid less attention to follow the speaking class. They joined between $90 \%$ and $95 \%$. Nevertheless, the five other students were still enthusiastic about joining the lecture of two subjects. Their participation is between $90 \%$ and $95 \%$. It seems that the interest of the students in getting involved in the two subjects is different. Although the students have different levels of attendance percentage in two subjects, they are still enthusiastic about joining the lecture. Their attendance in the two subjects is more than $90 \%$. The frequency of attendance is influenced by motivation and commitment. The students need to have sufficient motivation to get involved in the teaching-learning process (Zulkepli et al., 2020). To gain this kind of 
motivation, the students need to build a commitment to finish the study. The external and internal interference also take part in building motivation (Gump, 2005).

Graph 2. The average participation

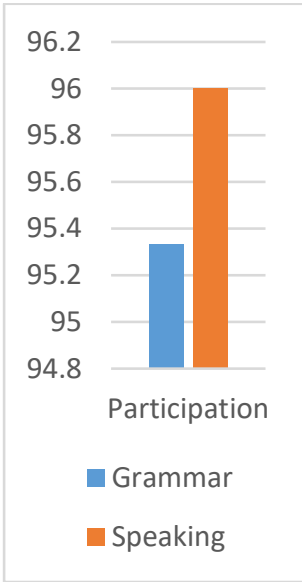

From graph 2, it is seen that most of the students are active in following the teachinglearning process in the two subjects. They paid more attention to joining a speaking lesson than a grammar lesson. Their attendance in speaking lectures is $96 \%$ while in grammar lectures are $95.3 \%$. the difference is very little. It is about $0.7 \%$. It shows that most of the students are interested in learning grammar and speaking. They wanted to learn grammar as much as speaking. The number of percentages shows their goodwill to take part in the teaching-learning process. Moreover, by attending the lectures, the students have a big opportunity to succeed in their studies. They experience much more knowledge building during taking part in the teaching-learning process (Jansen \& Suhre, 2010).

Graph 3. The score of task

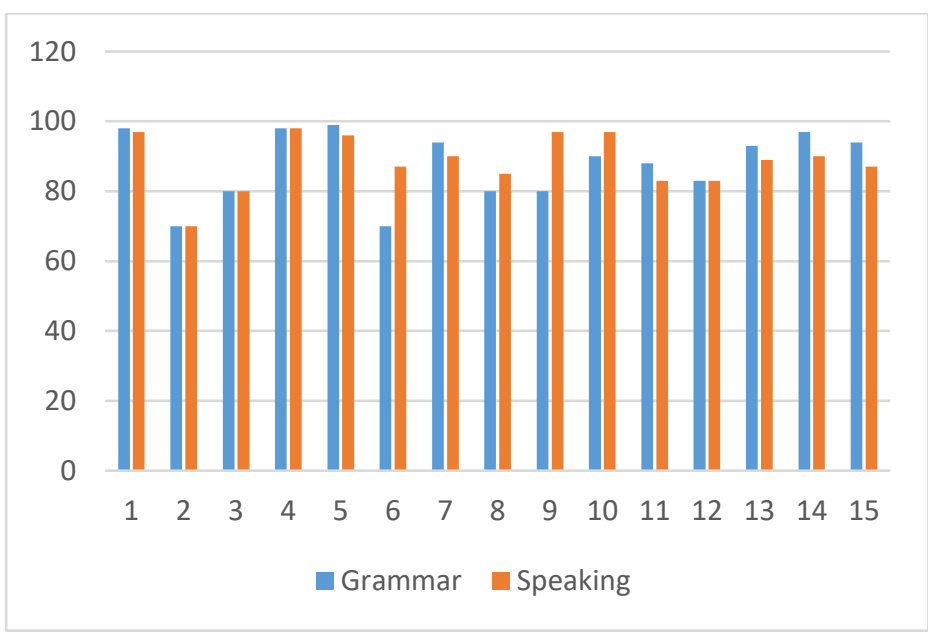

The students' ability to complete their tasks in grammar and speaking lessons is between $70 \%$ and $98 \%$. It is shown in graph 3. There are two students who did the task at $70 \%$ in grammar. They are students numbers 2 and 6 . There is one student who did his task $70 \%$ in speaking lessons. He is student number 2. The rest of the students complete their tasks between $80 \%$ and $98 \%$. It seems that only two students who need some assistance to complete the task. They need a certain detail explanation of the material they did not understand. It can be done through peer teaching or guidance from the teacher. Nevertheless, most of the students can 
complete their assignments very well. They are able to build their competence in grammar usage and speaking practice. Most of them did not face serious difficulty to do the task. Doing the task means gaining the goal of learning by completing the process (Willis, 1996).

Graph 4. The average of task

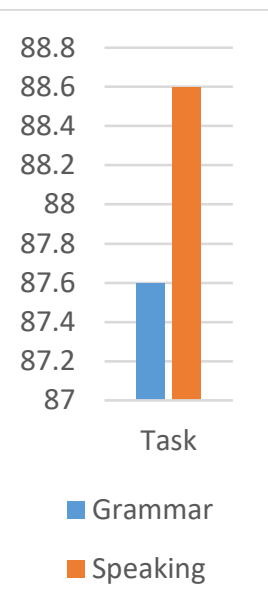

From graph 4 , it is seen that most of the students could accomplish their task $87.6 \%$ in grammar and $88.6 \%$ in speaking. It seems that most of them were able to do the task in the two subjects very well. The difference in completion from the two subjects is only $1 \%$. It is a very small percentage. It means that they did not experience serious problems doing the task. They could understand most of the material discussed in grammar and speaking. The task is a workplan that the students require to complete it to satisfy the goal of learning. By doing the task, the teacher can evaluate the level of absorbance of the material during the process of teaching-learning by the students (Ellis, 2003).

Graph 5. The score of midterm

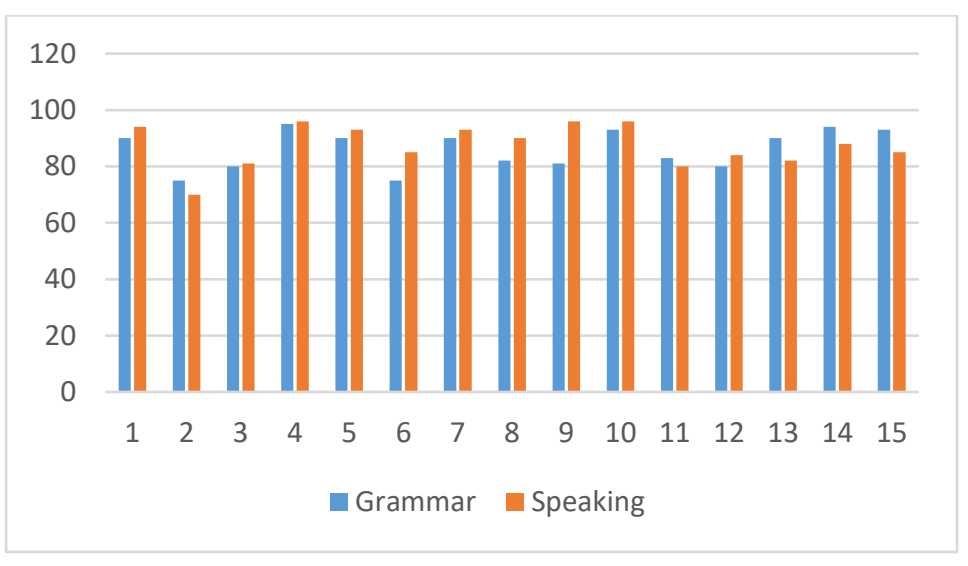

The graph 5 tells about the students' scores in the midterm test in subjects grammar and speaking. From the chart is seen that the students' number 2 and 6 got the scores between 70 and 75 in grammar and one student number 2 whose score in speaking is 70 . It seems that student number 2 is the lowest one in gaining the scores in the two subjects. He got 75 in grammar and 70 in speaking. This kind of achievement can be influenced by his accomplishment in his task in the two subjects. His completion task in grammar and speaking class is $70 \%$. It seems he needs to get some assistance from his friends or teacher. The other students got their midterm test scores between 80 and 96. It seems that the use of authentic 
material to support teaching-learning grammar has sufficient influence in bettering the students' competence in speaking. The role of the podcast to provide authentic sources helps students to understand how to implement grammar rules in speaking settings (Kolokdaragh, 2010). It is the benefit of using a gadget for educational purposes. It is not only for communication but also for teaching-learning needs (Dashtestani, 2014).

Graph 6. The average of midterm test

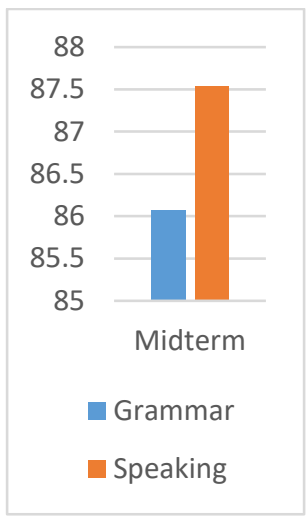

By seeing graph 6, it can be said that most of the students could get involved in the teaching-learning process very well. They got the scores between 86 and 87.5 in two subjects grammar and speaking. After attending the class more than $95 \%$ and accomplishing the task more than $87 \%$, most of the students could get the midterm test scores more than 86 in two subjects grammar and speaking. It seems that the completion of doing the task and the attendance in the classroom influenced the achievement in the midterm test. Moreover, giving guidance to the students to build vocabulary by using an electronic dictionary in learning grammar affects the students' fluency in speaking (Fraser, 2000). This kind of influence can be seen on the result of the midterm test as a picture of the success of the teaching-learning process in a half period of the semester.

Graph 7. The scores of the final test

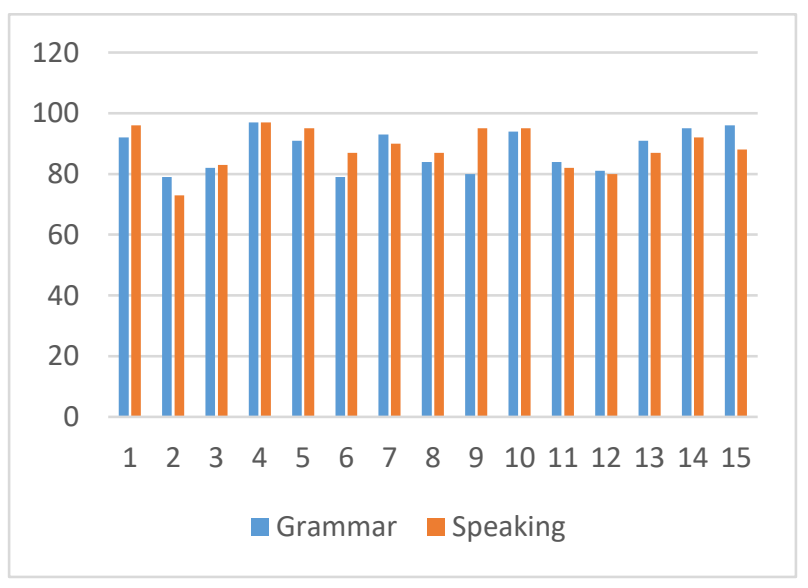

In graph 7, it is seen that the students's final test cores in grammar and speaking arre between 73 and 97 . The student number 2 is still the lowest one among his friends in gaining the final test score in speaking. He got 73 . He got progress after joining teaching-learning process after doing midterm test. He got 3 additional points from 70 become 73. It seems that 
he has a bit guidence and motivation to better his competence in speaking. Nevertheless, he could put himself at the same level with his 4 buddies in grammar. He got 80 . It shows an effort to better his competence in grammar usage. He got 5 additional points from 75 to 80 . The fourteen students got the scores between 80 and 97 in both subjects grammar and speaking. It is a bit better that the scores they gained in midterm test between 80 and 96 . Nevertheless, the result of learning grammar and speaking gets at satisfying achievement. The students could implement their knowledge in learning grammar into speaking. It can be seen on their scores in the two subjects grammar and speaking.

Graph 8. The average of final test

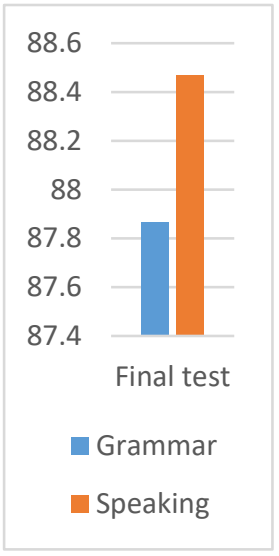

Graph 8 shows the students' average final test scores in two subjects grammar and speaking. Most of the students got 87.8 in grammar and 88.4 in speaking. They got progress compared with the midterm test. Their average midterm test scores are 86 in grammar and 87.5 in speaking. They got 1.8 additional points in grammar and 0.9 points in speaking. Nevertheless, their competence in grammar and speaking is very good after joining grammar and speaking class for a semester. The difference between the average final test scores in two subjects is 0.6. it is very small. It seems that the students got similar progress in learning grammar and speaking. In the process of learning grammar, the students experienced the implementation of translation method, noticing, listening, and conversation. It means that they develop four language skills in learning grammar (Ur, 2000). This communicative grammar influences the development of the students' competence in speaking as seen in graph 8 .

Graph 9. Overall of the assessment

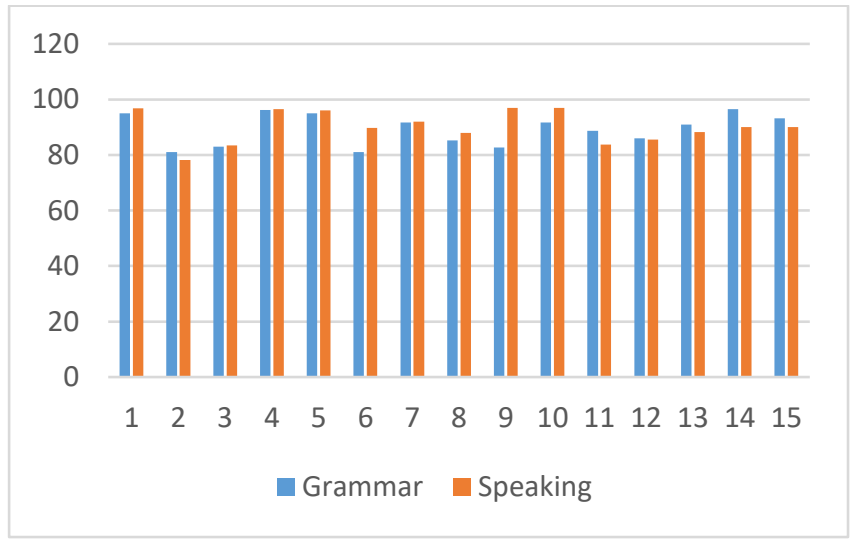


The overall assessment of teaching-learning grammar ang speaking can be seen on graph 9. It seems that the student number 2 got 78.3 on speaking. The rest of the students got between 80 and 96.7 in both subjects grammar and speaking. No one got below 80 in grammar lesson. It seems that the students understand how to implement grammar rules on the right context. Fourteen students got more than 80 in speaking lesson. They could express their ideas meaningfully to the other people. It seems the use of podcast and electronic dictionary develop the students competence in listening. This kind of ability influences the students' fluency in speaking (Asher, 2003). Krashen (1988) said that there is a strong relationship between listening and speaking skills.

Graph 10. The average of overall assessment

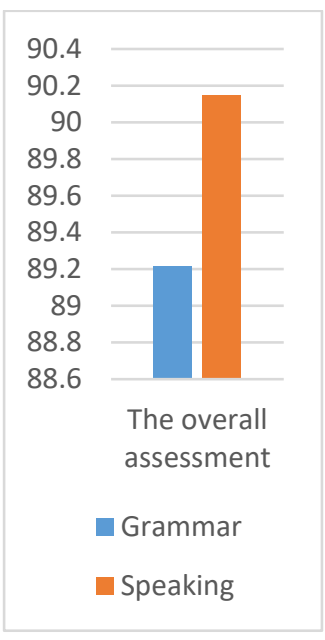

The result of overall activities in learning grammar and speaking can be seen in graph 10. Most of the students could develop their competence in grammar and speaking. It can be seen that their achievement is 89.2 in grammar and 90.15 in speaking. It seems that they enjoyed the flow of the teaching-learning process. The difference scores of the two subjects are 0.95 points. It looks like that there is a close relationship in the process of learning. To see the relationship between the two learning subjects, tracing the methodology of teaching grammar and speaking can clarify the causative result. It needs to dig some information about the approaches the teacher used in teaching subjects grammar and speaking.

\section{T-test}

To ensure the result, establishing a t-test is necessary. There are two steps to implement the t-test statistic. The first one is a normality test and the second is a statistic. The homogenous test is important to run statistics. It is a way to see that the data is not extremely high or low. To make this kind of test run, the hypothesis needs to be held. The result of the test can answer the normality of the data.

Hypothesis

H0: The data is distributed normally

H1: The data is not distributed normally

If p-value $>0.05, \mathrm{H} 0$ is accepted. Then, $\mathrm{H} 1$ is denied.

If $\mathrm{p}$-value $<0.05, \mathrm{H} 1$ is accepted. Then, $\mathrm{H} 0$ is denied. 
Anderson-Darling Normality Test

Table 3. Col A (Speaking)

$\mathrm{p}$ value $\quad 0.0547$

Pass normality test? Yes

Table 4. Col B (Grammar)

$\mathrm{p}$ value $\quad 0.0665$

Pass normality test? Yes

From Tables 3 and 4, it can be deduced that the data of the grammar and speaking scores pass the normality test. It is proven by meeting the hypothesis statement. in table 3 , it is stated that the p-value is 0.0547. it is $>0.05$. It means that H0 is accepted and H1 is denied. It could be said that the data in speaking is meeting the normality. Furthermore, in table 4, it is also stated that the $\mathrm{p}$-value is more than 0.05 . it is 0.0665 . It shows the acceptance of $\mathrm{HO}$ and the neglect of H1. It ensures the normality of the data in grammar.

From the analysis above, it shows that the data in grammar and speaking pass the normality test. It enables the two data to be used for further analysis. It means that no single score in both data grammar and speaking is too high or too low. The scores distributed normally. Later on, the data was inserted in the t-test for further results.

\section{Unpaired t-test (compare two data means)}

The data is unpaired. The resource of the data was derived from two different sources grammar and speaking score list. The scores are the average scores of the students. The statistic of this analysis proved the hypothesis. The result of it would be the guidance for confirming the result of the study.

Hypothesis

Ho: The two data have similar means

Ho: the two data have different means

If $\mathrm{p}$-value $<0.05, \mathrm{H} 0$ is accepted. Then, $\mathrm{H} 1$ is denied.

If $\mathrm{p}$-value $>0.05, \mathrm{H} 1$ is accepted. Then, $\mathrm{H} 0$ is denied.

Col A (Speaking) vs Col B (Grammar)

Table 5. Statistic

\begin{tabular}{lc}
\hline Mean \pm sd of Col A (Speaking) & $3132.000 \pm 4129.049$ \\
\hline Mean \pm sd of Col B (Grammar) & $4303.467 \pm 4559.621$ \\
\hline Difference of means & -1171.467
\end{tabular}




\begin{tabular}{ll}
\hline Lower Range & -4424.897 \\
\hline Upper Range & 2081.964 \\
\hline $\mathrm{t}$ & 0.738 \\
\hline $\mathrm{t}$, critical & 2.048 \\
\hline $\mathrm{p}$ value & 0.4669 \\
\hline
\end{tabular}

Are the means different $(\mathrm{p}<0.05) ? \quad$ No

One or two-tailed ? $\quad$ Two-tailed

Significance level at $95 \%$

From table 5, it is shown that the p-value is more than 0.05. It indicates the acceptance of $\mathrm{H} 0$. And by nature, $\mathrm{H} 1$ is denied. It is confirmed that the two data have similar means. It could be said that they support one to the other. It seems to happen the causative process in teaching grammar and speaking. Based on the tracing approaches used in the teaching-learning process of the two subjects grammar and speaking, there is a reciprocal method used to teach the two subjects. In teaching grammar, the teacher develops a translation-method, podcast, noticing, and conversation. They support the students' ability to practice speaking in speaking class. The teacher implemented a discussion approach to develop the students' fluency in speaking. It is clearly seen that implementing the communicative grammar method by developing a translation-method, podcast, noticing, and conversation better the students' competence in speaking.

\section{Tracing the approaches}

\section{The materials used in the grammar lesson}

To teach grammar, the teacher provided a list of words. He asked the students to find the meaning and pronunciation of their electronic dictionary. He explained the material in the students' mother tongue by constructing sentences from L1 to L2. To deepen the understanding of the material discussed, the teacher gave the exercises to translate the sentences from L1 to L2 and read them aloud.

To see how the grammar rules work on authentic material, the teacher asked the students to open the provided URL. It is a podcast. By clicking the URL, the students see a page of reading text with the audio record. The teacher asked them to click the audio button to listen to the correct pronunciation and intonation of the words. After finishing the listening, the teacher asked the students to find difficult words to translate. While searching the unfamiliar words, the students noticed the sentences by circling them to see the grammatical content (Yunus, 2017). To check the students' works, the teacher discussed them to ensure that the students understand the grammar discussed works on the passage. This kind of process helps the students construct sentences. The ability to build sentences appropriately affects the students' fluency in speaking. They can deliver understandable utterances (Hughes, 2002). By having the fluency, the students can answer the interlocutors' questions coherently by adapting their background knowledge (Hedge,2000). 
Since the function of the language is for communication both in spoken and written, the teacher asked the students to build their own sentences based on the grammar discussed (Wei, 2018). To meet the proper pronunciation, the teacher asked them to check the pronunciation of their electronic dictionary. Moreover, the teacher persuaded the students to practice speaking by adapting the grammar discussed with their peers (Vafadar \& Foo, 2020). By focusing on grammatical structures, vocabulary, and pronunciation, the students can get their fluency in speaking (Mazouzi, 2013).

\section{The materials used in speaking lesson}

To teach speaking, the teacher grouped the students into some clusters. To enhance the speaking atmosphere, the teacher provided some topics to choose for each cluster. One of the members in every cluster is as a leader. He led the discussion. At the end of the discussion, he chose one of his members to present the summary of the discussion in front of the class. The teacher gave the feedback of each presenter by raising some questions and giving suggestions. This kind of strategy can build the students' motivation to get involved in the teaching-learning process (Littlewood, 2007).

\section{Correlation material}

In teaching grammar, the teacher use translation-method, podcast, noticing, and conversation. It seems that the teacher taught grammar communicatively. It leads the students to be able to adapt the grammar rules into spoken and written. While in teaching speaking, the teacher invited the students to conduct a discussion based on the chosen topic. The students enjoy the flow of the activity. It looks like the students could implement their vocabulary and grammar background knowledge into speaking. It develops the students' fluency in practicing speaking as seen in graph 10.

It could be said that some components of translation-method, podcast, noticing, and conversation in teaching grammar develop the speaking competence in learning speaking. The teacher did in teaching grammar was applying a communicative-grammar method. Based on the result of the t-test, it is stated that the result of learning grammar and speaking has a very close relationship. This kind of phenomenon answers the research question that the communicative grammar method is effective to develop the students' competence in speaking. It also satisfies the aim of this study to prove whether the implementation of the communicative grammar method enhances the students' competence in speaking. The three skills vocabulary, grammar, and pronunciation build the students' ability in practicing speaking (Lukitasari, 2003).

The result of this study is essential to complete the previous studies. The implementation of noticing by using the authentic material taken from the podcast can support the methodology of them. Moreover, the teachers and students can adapt the communicative grammar to boost the teaching-learning process in grammar and speaking lessons. Other researchers are able to develop the result of this study into some further.

\section{CONCLUSION}

Speaking is an important part of delivering ideas to others. Some factors like vocabulary building, grammatical usage, and pronunciation hamper the students to practice speaking. As 
the aim of meaningful language teaching on SFL, the implementation of communicative grammar to lead the students to develop their competence in learning speaking is effective. Using translation-method, podcasts, noticing, and conversation in applying the communicative-grammar method helps the students to better their competence in speaking. This kind of result would be beneficial for teachers and students to develop grammar and speaking learning in the classroom. It is also an inspiring reference for the other researchers to develop it into some deeper.

\section{REFERENCE}

Asher, J. J. (2003). Learning Another Language through Actions (6th edition). Los Gatos, CA: Sky Oaks Productions, Inc.

Baydikova, N. L., and Davidenko, Y.S. (2019). Teaching Communicative Grammar to Technical University EFL Learners. IOP Conf. Series: Earth and Environmental Science 272. Derived from $\underline{\text { https://iopscience.iop.org/article/10.1088/1755- }}$ $1315 / 272 / 3 / 032170 / p d f$

Bongey, S.B., Cizadlo, G., \& Kalnback, L. (2006). Explorations in course casting: Podcasts in higher education. CampusWide Information Systems, 23(5), 350-367.

Butt, D., Fahey, R., Feez, S., Spinks, S., \& Yallop, C. (2000). Using Functional Grammar: An Explorer's Guide. Sydney: National Centre for English Language Teaching and Research Macquarie University.

Dashtestani, R. (2014). The Use of Laptops for Learning English as a Foreign Language (EFL): Merits, Challenges, and Current Practices. TESOL International Journal Volume 9 Issue 1, 106-124. Derived from https://www.elejournals.com/tesol-journal/tesol-journalvolume-8-issue-1/

Eggins, S. (2004). An introduction to systemic functional linguistics (2nd ed.). London: bloomsbury Academic.

Ellis, R. (2003). Task-based Language Teaching. Oxford: Oxford University Press.

Fraser, H. (2000). Coordinating Improvements in Pronunciation Teaching for Adult Learners of English as a Second Language. Department of Education, Training and Youth Affairs, Canberra.

Gee, J. P. (2014).An Introduction to Discourse Analysis:Theory and Method. Newyork: Routledge.

Gump, S. E. (2005). The cost of cutting class: attendance as a predictor of success. College Teaching, 53(1), 21- 26.

Halliday, M. A. K. (1978). Language as social semiotic. London: Edward Arnold

Halliday, M.A.K., \& Matthiessen, C. M. I. M. (2014). An introduction to functional grammar. Oxon \& New York: Routledge. 
Halliday, M. A. K. (2009). The gloosy gandoderm: Systemic functional linguistics and translation.

Chinese

Translators

Journal, 1, 17-26.

Halliday, M. A. K. (1961). Categories of the theory of grammar. Word, 17, 241-292.

Halliday, M. A. K., \& Matthiessen, C. M. I. M. (2014). Halliday' $s$ Introduction to Functional Grammar. New York: Routledge.

Harmer J. (2002). The Practice of English Language Teaching, third edition. England. Cambridge.

Hedge, T. (2000). Teaching and Learning in the Language Classroom. Oxford: Oxford University Press.

Ho, P.V.P., \& Binh, N.T. (2014). The Effects of Communicative Grammar Teaching on Students'Achievement of Grammatical Knowledge and Oral Production. English Language Teaching; Vol. 7, No. 6. Derived from https://www.researchgate.net/publication/264862539_The_Effects_of_Communicative _Grammar_Teaching_on_Students'_Achievement_of_Grammatical_Knowledge_and Oral_Production

Hughes, R. (2002). Teaching and Researching Speaking. New York: Pearson Education.

Jansen, E., Suhre, C., \& André, S. (2017). Transition to an international degree programme. Preparedness, firstyear experiences and success of students of different nationalities. In E. Kyndt, V. Donche, K. Trigwell, \& S. Lindblom-Y

Kaharuddin, A. (2018). The communicative grammar translation method: a practical method to teach communication skills of English. Eternal, vol. 4, no. 2. 232254. Derived from http://journal.uin-alauddin.ac.id/index.php/eternal/article/view/6292

Kolokdaragh, R. V. (2010). ESL/EFL Learners' Perception of Their Pronunciation Needs and Strategies. 41st Annual State CATESOL Conference in Santa Clara, CA, April 23, 2010.

Koşar, G., \& Bedir, H. (2014). Strategies-based instruction: A means of improving adult EFL learners' speaking skills. International Journal of Language Academy, 2(3), 12- 26.

Koussouhon, L. A., \& Dossoumou, A. M. (2015). “Analyzing Interpersonal Metafunction through Mood and Modality in Kaine Agary's Yellow-Yellow from Critical Discourse and Womanist Perspective". International Journal of English Linguistics, 5(6), 20.

Krashen, S. D. (1988). Second Language Acquisition and Second Language Learning. New York: Prentice-Hall.

Littlewood, W. (2007). Communicative Language Teaching. Cambridge: Cambridge University Press.

Luke, A., Freebody, P., Cazden, C., \& Lin, A.(2005). Singapore pedagogy coding manual.Singapore: Centre for Research for Pedagogy and Practice.

Lukitasari, N. (2003). Students' Strategies in Overcoming Speaking Problems in Speaking Class. University of Muhammadiyah Malang. 
Martin, J. R., Matthiessen, C. M. I. M., \& Painter, C. (2010). Deploying functional grammar. Beijing: Commercial Press.

Matthiessen, CMIM. 2010. Systemic functional linguistics developing. Annual Review of Functional Linguistics 2:8-63.

Mazouzi, S. (2013). Analysis of Some Factors Affecting Learners' Oral Performance. A Case Study: 3rd Year Pupils of Menaa's Middle Schools. M. A. Dissertation, Department of Foreign Languages, English Division, Faculty of Letters and Languages, Mohamed Khider University of Biskra, People's Democratic Republic of Algeria.

Ur, P. (2000). A Course in Language Teaching: Practice and Theory. Cambridge: Cambridge University Press.

Wei, L., Lin, H. H.,\& Litton, F. (2018). Communicative Language Teaching (CLT) in EFL Context in Asia. Asian Culture and History; Vol. 10, No. 2. Derived from http://dx.doi.org/10.5539/ach.v10n2p1

Vafadar, H., and Foo, T.C.V. (2020). The effects of communication strategies instruction on Iranian intermediate EFL. learners' willingness to communicate. Asian EFL Journal, Volume 24 Issue 4, 130-173. Derived from https://www.asian-efl-journal.com/maineditions-new/2020-main-journals/volume-24-issue-4-july-2020/

Willis, D. (1996). A Framework for Task-Based Learning. London: Longman.

Yunus, M. (2017). English lecturers' perceptions of task-based reading teaching at ABA Universitas Muslim Indonesia. Asian EFL Journal, issue 98, 4-15. Derived from http://asian-efl-journal.com/wp-content/uploads/AEJ-TA-98-February-2017.pdf

Zulkepli, N., Madzlan, N.A., Kesevan, H.V., Amalina, S.N., and Tajuddin, A. (2020). L2 motivational self system as predictors of in-class and out-of-class willingness to communicate in a multicultural context, Asian EFL Journal, Volume 24 Issue 4, 79-100. Derived from https://www.asian-efl-journal.com/main-editions-new/2020-mainjournals/volume-24-issue-4-july-2020/ 